\title{
ANALISIS KESALAHAN BERBAHASA TATARAN MORFOLOGI DALAM TAJUK RENCANA SURAT KABAR KOMPAS
}

\author{
Alber $^{1}$, Rhani Febria ${ }^{2}$, Riana Fatmalia ${ }^{3}$ \\ Universitas Islam Riau, Pekanbaru, Indonesia ${ }^{1,2,3}$ \\ alberuir@edu.uir.ac.id ${ }^{1}$,rhanifebria@du.uir.ac.id', riana.fauri@gmail.com ${ }^{3}$
}

\begin{abstract}
Language error analysis is a study about disorder of language use based on grammatical rules. This research is aimed to analyze and interpret morphological errors in Kompas Editorials. It works on perspective content analysis method by applying documentation and hermeneutic techniques. Data collection techniques applied in this research by reading, recording, and grouping the data based on morphological categories. This research reveals that inappropriate affix uses, affix omission in particular use of prefix, suffix, and confix. To conclude, the use of official, accurate, acceptable Indonesian language should be concerned in writing the news.
\end{abstract}

Keywords: analysis, language error, Kompas, editorial

\begin{abstract}
ABSTRAK
Analisis kesalahan berbahasa merupakan ilmu yang mempelajari atau membahas penggunaan bahasa yang tidak sesuai dengan atauran yang telah ditentukan berdasarkan tata bahasa baku/standar baku, hal tersebut masih ditemukan dalam surat harian Kompas khususnya dalam tajuk rencana. Kesalahan tersebut terjadi khususnya pada tataran morfologi. Oleh karena itu, penelitian ini dilakukan dengan tujuan menganalisis dan menginterpretasi kesalahan berbahasa tataran morfologi dalam tajuk rencana surat kabar Kompas. Penelitian ini menggunggunakan metode content analysis bersifat presprektif. Teknik pengumpulan data menggunakan teknik dokumentasi dan hermeneutik. Data penelitian ini bersumber dari tajuk rencana surat kabar harian Kompas. Data yang diteliti didokumentasi dengan cara membaca, mencatat selanjutnya disimpulkan dan dikelompokkan berdasarkan penggunaan tataran morfologi. Kesalahan berbahasa dalam tajuk rencana surat kabar Kompas terdapat kesalahan berbahasa dalam tataran morfologi khususnya penggunaan afiks yang tidak tepat, penghilangan afiks khusunya penghilangan prefiks, sufiks, dan konfiks. Berdasarkan simpulan penelitian disarankan kepada surat kabar Kompas seharusnya mengutamakan bahasa Indonesia baku, jelas, lugas, dan disesuai dengan kaidah yang berlaku.
\end{abstract}

Kata Kunci: analisis, kesalahan berbahasa, Kompas, tajuk rencana

\section{PENDAHULUAN}

Mengingat pentingnya peran pembinaan bahasa dalam pengembangan mutu sumber daya manusia, perlu dilakukan berbagai rencana dan upaya yang terpadu dan terarah, berdasarkan suatu kebijakan bahasa yang komprehensif agar pembinaan bahasa itu dapat dilaksanakan secara lebih efisien dan efektif. Rencana dan upaya itu sama sekali tidak akan memadai kalau hanya dilakukan oleh pusat pembinaan dan pengembangan bahasa saja. Dalam hal ini, media massa harus tampil sebagai salah satu pihak yang memiliki peran dan tanggung jawab yang sangat menentukan mutu pemakaian bahasa Indonesia (Alwi, 2000 $: 101)$.

Surat kabar atau koran merupakan salah satu contoh dari media massa yang berperan penting dalam pembinaan bahasa Indonesia mempunyai keunggulan tersendiri dibandingkan media lain. Keunggulan Surat kabar selain dapat dibaca berulang-ulang juga dapat menginformasikan berita aktual secara mendetail. Seorang wartawan dalam menulis berita di media massa harus memperhatikan penggunaan bahasa, baik ejaan, pemilihan 
kata, dan pembentukan kata, sehingga informasi yang disampaikan dimengerti dan dipahami oleh khalayak ramai. Sehubungan dengan itu, Rahman (1998:11) mengatakan bahwa tuntutan utama kepada wartawan supaya wartawan menggunakan bahasa baku, ejaan harus tetap sesuai dengan kaidah, pilihan dan pembentukan kata dan kalimat harus sesuai dengan kelaziman, tanpa menghapus kemungkinan penyerapan unsur luar bahasa Indonesia acap mengikuti sistem yang telah ditetapkan dalam EYD.

Surat kabar daerah maupun nasional yang beredar di Pekanbaru khususnya surat kabar Kompas banyak dijumpai penggunaan kosakata dalam penyampaian beritanya, terutama dalam tajuk rencana. Kosakata tersebut masih ditemukan kesalahan dalam penulisan. sehingga mengakibatkan ketidakefektifan makna. Terdapatnya kesalahan dalam bahasa surat kabar, maka akan dijadikan contoh dalam proses berbahasa oleh masyarakat, haruslah diingat bahwa yang membaca surat kabar dan majalah bukanlah hanya masyarakat dari kalangan terpelajar, melainkan juga sampai kepada masyarakat bawah (Badudu, 1988:138). Oleh karena itu, bahasa surat kabar perlu dikaji dan ditinjau kembali kesalahannya melalui analisis kesalahan berbahasa, terutama pada tataran morfologi. Tajuk rencana Kompas dipilih di dalam penelitian ini karena harian Kompas merupakan media yang dibaca oleh berbagai kalangan mulai dari kalangan strata ekonomi dan sosial, menengah ke atas yang tercermin dari latar belakang pendidikan dan ekonomi. Tentu, selain menarik perhatian pembaca dengan berita-berita terbaru dan aktual juga banyak meraih penghargaan dan rekor seperti pada tahun 2015, Kompas meraih penghargaan emas kategori surat kabar nasional terbaik (The Best of National Newspaper) IPMA 2015 untuk edisi 16 Februari 2014 dan 20 Oktober 2014. (https://id.wikipedia.org/wiki/Kompas). Namun sayang, surat kabar terbaik nasional tersebut masih terdapat kesalahan dalam penyampain informasi kepada pembaca, khususnya pada tataran morfologi

Menurut Ramlan (2001:21) morfologi adalah bagian dari ilmu bahasa yang membicarakan atau yang mempelajari seluk- beluk bentuk kata serta pengaruh perubahanperubahan bentuk kata terhadap golongan dan arti kata, atau dengan kata lain dapat dikatakan bahwa morfologi mempelajari seluk-beluk bentuk kata itu, baik fungsi gramatik maupun fungsi semantik. Menurut Setyawati (2010:49) kesalahan tataran morfologi dapat dianalisis berdasarkan klasifikasi kesalahan berbahasa antara lain: (1) penghilangan afiks, (2) bunyi yang seharusnya luluh tidak diluluhkan, (3) peluluhan bunyi yang seharusnya tidak luluh, (4) penggantian morf, (5) Penyingkatan morf mem-, men-, meng-, meny-, dan menge-, (6) Penggunaan afiks yang tidak tepat, (7) penentuan bentuk dasar yang tidak tepat, (8) Penempatan afiks yang tidak tepat pada gabungan kata, (9) pengulangan kata majemuk yang tidak tepat.

Berdasarkan uraian di atas, penulis tertarik untuk meneliti analisis kesalahan berbahasa tataran morfologi dalam tajuk rencana surat kabar Kompas dengan tujuan menganalisis dan menginterpretasikan kesalahan berbahasa tataran morfologi dalam tajuk rencana surat kabar Kompas. Hasil penelitian ini diharapkan dapat memberikan informasi dan referensi bagi para peneliti atau pihak lain yang hendak meneliti masalahmasalah yang berhubungan dengan analisis kesalahan berbahasa dalam berbagai aspek serta sebagai umpan balik agar wartawan lebih berhati-hati dalam dalam menulis dan menyajikan berita khususnya wartwan pada surat kabar Kompas.

\section{METODOLOGI PENELITIAN}

Penelitain ini menggunakan metode content analisis. Menurut Krippendorff (1991:1) metode analisis isi merupakan metode yang digunakan untuk mengungkapkan studi-studi terng pers dalam skala besar, penelitian sosiologis dan linguistik, terutama media mutakhir. Penelitaian analisis isi secara mendasar berorientasi emoiris, bersifat menjelaskan, berkaitan dengan gejala-gejala nyata dan bertujuan predikatif dan serta cenderuhg bersifat preskriptif. Menurut Sudaryanto (1988:62-63) penelitian preskriptif adalah penelitian yang cenderung menitikberatkan perhatiannya pada penggunaan bahasa yang dianggap baik dan 
benar saja. Penelitian preskriptif

mempertimbangkan terlebih dahulu benar salahnya pemakaian bahasa menurut norma atau kriteria tertentu. Selanjutnya Kridalaksana (2008:199) menjelaskan bahwa preskriptif bersangkutan dengan paham bahwa ada standar mutlak mengenai betul-salah dalam bahasa dan bahwa tujuan analisis bahasa adalah menyusun norma-norma pemakaian bahasa. Penelitian preskriptif digunakan karena penulis ingin menganalisis secara akurat penerapan kaidah bahasa Indonesia khususnya dalam tajuk rencana surat kabar harian Kompas. Data yang akan diperoleh dikumpulkan, dianalisis dan dipilih yang relevan guna keperluan penelitian.

\section{HASIL DAN PEMBAHASAN}

Berdasarkan peneltian yang telah dilakukan, kesalahan berbahasa tataran morfologi dalam tajuk rencana surat kabar Kompas dianalisis sesuai teori yang relevan seperti di bawah ini.

Data 1

Kebijakan proteksionis (1) AS dan negara maju lain akan membuat negara seperti Tiongkok mengalihkan produknya ke pasar lain, termasuk Indonesia. (Publikasi Rabu, 1 Februari 2017 dengan judul tajuk "Daya Saing Ekspor IKM")

Berdasarkan data (1) di atas, penulisan proteksionis tidak sesuai dengan aturan atau kaidah bahasa Indonesia. Kesalahan tersebut terjadi karena penggunaan afiks yang tidak tepat. Penggunaan afiks bahasa asing yang tidak tepat, khususnya penggunaan sufiks $-i s$ pada kata proteksionis. Penulisan kata proteksionis seharusnya ditulis proteksionisme dengan menggunakan sufiks -isme. Menurut Depdiknas (2008:900) proteksionisme adalah paham bahwa ekonomi dalam negeri harus dilindungi pemerintah dari persaingan luar negeri. Dengan demikan kalimat pada data (1) dapat diperbaiki menjadi, "Kebijakan proteksionisme AS dan negara maju lain akan membuat negara seperti Tiongkok mengalihkan produknya ke pasar lain, termasuk Indonesia."
Data 2

KTP palsu jelang (2) pilkada (Publikasi Kamis, 2 Februari 2017 dengan judul tajuk "KTP Palsu Jelang Pilkada")

Berdasarkan data (2) di atas, penulisan jelang tidak sesuai dengan aturan atau kaidah bahasa Indonesia. Kesalahan tersebut terjadi karena penghilangan afiks (prefiks, sufiks, infiks, konfiks) khususnya penghilangan prefiks meng- (varian me-, mem-, men-,mengemeny-) pada kata jelang. Penulisan kata jelang seharusnya ditulis menjelang dengan menggunakan prefiks meng- varian men-. Menurut Depdiknas (2008:465) menjelang adalah mengunjungi; menengok; menjenguk; menghadap. Dengan demikan kalimat pada data (2) dapat diperbaiki menjadi, "KTP palsu menjelang pilkada."

Data 3

Temuan KTP palsu ini pun menunjukkan administrasi kependudukan di negara kita masih perlu (3) pembenahan. (Publikasi Kamis, 2 Februari 2017 dengan judul tajuk "KTP Palsu Jelang Pilkada")

Berdasarkan data (3) di atas, penulisan perlu tidak sesuai dengan aturan atau kaidah bahasa Indonesia. Kesalahan tersebut terjadi karena penghilangan afiks (prefiks, sufiks, infiks, konfiks) khususnya penghilangan prefiks meng- (varian me-, mem-, men-,mengemeny-) pada kata perlu. Penulisan kata perlu seharusnya ditulis memerlukan dengan menggunakan prefiks meng-varian mem- serta diikuti sufiks -kan atau konfiks mem-...-kan (penghilangan konfiks mem-...-kan). Menurut Depdiknas (2008:861) memerlukan adalah memandang perlu (penting, berguna, dan sebagainya); mementingkan; mengutamakan; membutuhkan; dan mengahajatkan. Dengan demikan kalimat pada data (3) dapat diperbaiki menjadi, "Temuan KTP palsu ini pun menunjukkan administrasi kependudukan di negara kita masih memerlukan pembenahan."

Data 4

Kita tahu (4) Presiden AS Donal Trump telah membatalkan 
(Publikasi Kamis, 2 Februari 2017 dengan judul tajuk "Afrika sebagai Peluang Ekonomi”)

Berdasarkan data (4) di atas, penulisan tahu tidak sesuai dengan aturan atau kaidah bahasa Indonesia. Kesalahan tersebut terjadi karena penghilangan afiks (prefiks, sufiks, infiks, konfiks) khususnya penghilangan prefiks meng- (varian me-, mem-, men-, mengemeny-) pada kata tahu. Penulisan kata tahu seharusnya ditulis mengetahui dengan menggunakan prefiks meng- varian mengeserta diikuti sufiks $-i$ atau konfiks menge-...-i (penghilangan konfiks menge-...-i). Menurut Depdiknas (2008:1121) mengetahu adalah memaklumi; menyaksikan; tahu akan; mengenal; menyadari; dan menginsyafi. Dengan demikan kalimat pada data (4) dapat diperbaiki menjadi, "Kita mengetahui Presiden AS Donal Trump telah membatalkan ......"

Data 5

Tak cukup hanya retorika (5) (Publikasi Sabtu, 4 Februari 2017 dengan judul tajuk "Tak Cukup Hanya Retorika")

Berdasarkan data (5) di atas, penulisan retorika tidak sesuai dengan aturan atau kaidah bahasa Indonesia. Kesalahan tersebut terjadi karena penghilangan afiks (prefiks, sufiks, infiks, konfiks) khususnya penghilangan prefiks ber- (varian be-,dan bel-) pada kata retorika yang tidak dikesplisitkan. Penulisan kata retorika seharusnya ditulis beretorika dengan menggunakan prefiks ber- varian beserta. Menurut Depdiknas (2008:953) retorika adalah keterampilan berbicara secara efektif. Dengan demikan kalimat pada data (5) dapat diperbaiki menjadi, "Tak cukup hanya beretorika"

Data 6 dan 7

Langkah nyata dan keras perlu (6) karena tak cukup hanya punya (7) makna. (Publikasi Sabtu, 4 Februari 2017 dengan judul tajuk "Tak Cukup Hanya Retorika”)

Berdasarkan data (6) di atas, penulisan perlu tidak sesuai dengan aturan atau kaidah bahasa Indonesia. Kesalahan tersebut terjadi karena penghilangan afiks (prefiks, sufiks, infiks, konfiks) khususnya penghilangan konfiks di-...-kan pada kata perlu. Penulisan kata perlu seharusnya ditulis diperlukan. Menurut Depdiknas (2008:861) perlu adalah harus; penting; dan butuh. Sementara itu, data (7) di atas, penulisan punya juga tidak sesuai dengan aturan atau kaidah bahasa Indonesia. Kesalahan tersebut terjadi karena penghilangan afiks (prefiks, sufiks, infiks, konfiks) khususnya penghilangan prefiks meng- (varian me-, mem-, men-,menge- meny-) pada kata punya. Penulisan kata punya seharusnya ditulis mempunyai dengan menggunakan prefiks meng-varian mem- serta diikuti sufiks $-i$ atau konfiks $m e m-\ldots-i$ atau kesalahan yang tejadi pada penghilangan konfiks mem-...-i. Menurut Depdiknas (2008:908) mempunyai adalah memiliki dan menaruh. Dengan demikan kalimat pada data (6) dan (7) dapat diperbaiki menjadi, "Langkah nyata dan keras diperlukan karena tak cukup hanya mempunyai makna.

Data 8

Tak selesai dengan relokasi (8). (Publikasi Rabu, 8 Februari 2017 dengan judul tajuk "Tak Selesai dengan Relokasi”)

Berdasarkan data (8) di atas, penulisan relokasi tidak sesuai dengan aturan atau kaidah bahasa Indonesia. Kesalahan tersebut terjadi karena penghilangan afiks (prefiks, sufiks, infiks, konfiks) khususnya penghilangan prefiks meng- (varian me-, mem-, men-,mengemeny-) pada kata relokasi. Penulisan kata relokasi seharusnya ditulis merelokasi dengan menggunakan prefiks meng- varian me(penghilangan prefiks me-). Menurut Depdiknas (2008:944) merelokasi adalah memindahkan tempat. Dengan demikan kalimat pada data (8) dapat diperbaiki menjadi, "Tak selesai dengan merelokasi."

Data 9

Penguasa seperti itu lupa (9) bahwa kekuasaan mereka berasal dari rakyat. (Publikasi Kamis, 9 Februari 2017 dengan judul tajuk "Kejahatan Kemanusian Damaskus") 
Berdasarkan data (9) di atas, penulisan lupa tidak sesuai dengan aturan atau kaidah bahasa Indonesia. Kesalahan tersebut terjadi karena penghilangan afiks (prefiks, sufiks, infiks, konfiks) khususnya penghilangan prefiks meng- (varian me-, mem-, men-,mengemeny-) pada kata lupa. Penulisan kata lupa seharusnya ditulis melupakan dengan menggunakan prefiks meng- varian me- serta diikuti sufiks -kan atau konfiks me-...-kan (penghilangan konfiks me-...-kan). Menurut Depdiknas (2008:690) melupakan adalah lupa akan; tidak ingat akan; menjadikan lupa; melalaikan; dan tidak mengindahkan. Dengan demikan kalimat pada data (3) dapat diperbaiki menjadi, "Penguasa seperti itu melupakan bahwa kekuasaan mereka berasal dari rakyat."

Data 10

Peluang kebijakan proteksionistis (10) AS (Publikasi Rabu, 11 Februari 2017 dengan judul tajuk "Peluang Kebijakan Proteksionistis AS")

Berdasarkan data (10) di atas, penulisan proteksionistis tidak sesuai dengan aturan atau kaidah bahasa Indonesia. Kesalahan tersebut terjadi karena penggunaan afiks yang tidak tepat. Penggunaan afiks bahasa asing yang tidak tepat, khususnya penggunaan sufiks $-i s$ pada kata proteksionistis. Penulisan kata proteksionistis seharusnya ditulis proteksionisme dengan menggunakan sufiks -isme. Menurut Depdiknas (2008:900) proteksionisme adalah paham bahwa ekonomi dalam negeri harus dilindungi pemerintah dari persaingan luar negeri. Dengan demikan kalimat pada data (10) dapat diperbaiki menjadi, "Peluang kebijakan proteksionisme AS."

\section{Data 11}

Pemerintahan Trump perlu (11) pendekatan baru untuk menanggapi program nuklir Korut.(Publikasi Rabu, 15 Februari 2017 dengan judul tajuk "Hidup Dialog 6 Pihak")

Berdasarkan data (11) di atas, penulisan perlu tidak sesuai dengan aturan atau kaidah bahasa Indonesia. Kesalahan tersebut terjadi karena penghilangan afiks (prefiks, sufiks, infiks, konfiks) khususnya penghilangan prefiks meng- (varian me-, mem, men-,menge- meny-) pada kata perlu. Penulisan kata perlu seharusnya ditulis memerlukan dengan menggunakan prefiks meng- varian mem- serta diikuti sufiks -kan atau konfiks mem-...-kan (penghilangan konfiks mem-...-kan). Menurut Depdiknas (2008:861) memerlukan adalah memandang perlu (penting, berguna, dan sebagainya); mementingkan; mengutamakan; membutuhkan; dan mengahajatkan. Dengan demikan kalimat pada data (11) dapat diperbaiki menjadi, "Pemerintahan Trump memerlukan pendekatan baru untuk menanggapi program nuklir Korut."

Data 12

Apalagi China menyebut (12) salah satu penyebab friksi ini adalah AS dan Korsel .... (Publikasi Rabu, 15 Februari 2017 dengan judul tajuk "Hidup Dialog 6 Pihak")

Berdasarkan data (12) di atas, penulisan menyebut tidak sesuai dengan aturan atau kaidah bahasa Indonesia. Kesalahan tersebut terjadi karena penghilangan afiks (prefiks, sufiks, infiks, konfiks) khususnya penghilangan sufiks - kan pada kata menyebut. Penulisan kata meyebut seharusnya ditulis menyebutkan dengan menambahkan sufiks kan. Menurut Depdiknas (2008:1007) menyebutkan adalah menyebut untuk orang lain; mengatakan dan laian-lain. Dengan demikan kalimat pada data (12) dapat diperbaiki menjadi, "Apalagi China menyebutkan salah satu penyebab friksi ini adalah AS dan Korsel ....."

Data 13

Kenapa (13) Flynn harus berbohong? (Publikasi Kamis, 16 Februari 2017 dengan judul tajuk "Guncangan Pertama Kabinet Trump")

Berdasarkan data (13) di atas, penulisan kenapa tidak sesuai dengan aturan atau kaidah bahasa Indonesia. Kesalahan tersebut terjadi karena penghilangan afiks (prefiks, sufiks, infiks, konfiks) khususnya 
penghilangan prefiks meng- (varian me-, mem, men-,menge- meny-) pada kata kenapa. Penulisan kata kenapa seharusnya ditulis mengapa dengan menggunakan prefiks meng-. Menurut Depdiknas (2008:59) mengapa adalah kata tanya untuk menayakan sebab, alasan atau perbuatan. Dengan demikan kalimat pada data (13) dapat diperbaiki menjadi, "mengapa Flynn harus berbohong?"

\section{Data 14}

Mengapa Trump yang sudah dilapori (14) oleh badan intelijen ..... (Publikasi Kamis, 16 Februari 2017 dengan judul tajuk "Guncangan Pertama Kabinet Trump")

Berdasarkan data (14) di atas, penulisan dilapori tidak sesuai dengan aturan atau kaidah bahasa Indonesia. Kesalahan tersebut terjadi karena penghilangan afiks (prefiks, sufiks, infiks, konfiks) khususnya penghilangan sufiks - kan yang diganti dengan sufiks - $i$ pada kata dilapori. Penulisan kata dilapori seharusnya ditulis dilaporkan. Menurut Depdiknas (2008:640) lapor adalah memberitahukan. Dengan demikan kalimat pada data (14) dapat diperbaiki menjadi, "Mengapa Trump yang sudah dilaporkan oleh badan intelijen ......"

\section{Data 15}

Dalam konteks tenun kebangsaan, pasangan calon juga punya (15) tanggung jawab untuk menjaga tidak terkoyaknya tenun kebangsaan. (Publikasi Jumat, 17 Februari 2017 dengan judul tajuk "Merajut Tenun Kebangsaan")

Berdasarkan data (15) di atas, penulisan punya tidak sesuai dengan aturan atau kaidah bahasa Indonesia. Kesalahan tersebut terjadi karena penghilangan afiks (prefiks, sufiks, infiks, konfiks) khususnya penghilangan prefiks meng- (varian me-, mem, men-,menge- meny-) pada kata punya. Penulisan kata punya seharusnya ditulis mempunyai dengan menggunakan prefiks meng- varian mem- serta diikuti sufiks $-i$ atau konfiks mem-...-i (penghilangan konfiks mem...-i). Menurut Depdiknas (2008:908) mempunyai adalah memiliki; menaruh. Dengan demikan kalimat pada data (15) dapat diperbaiki menjadi, "Dalam konteks tenun kebangsaan, pasangan calon juga mempunyai tanggung jawab untuk menjaga tidak terkoyaknya tenun kebangsaan."

Data 16

Jika ada kesalahan, bisa jadi timbul (16) perang besar yang risikonya bisa melenyapkan Korut. (Publikasi Sabtu, 18 Februari 2017 dengan judul tajuk “Jong Nam Membayar Kritiknya?")

Berdasarkan data (16) di atas, penulisan timbul tidak sesuai dengan aturan atau kaidah bahasa Indonesia. Kesalahan tersebut terjadi karena penghilangan afiks (prefiks, sufiks, infiks, konfiks) khususnya penghilangan prefiks meng- (varian me-, mem, men-,menge- meny-) pada kata timbul. Penulisan kata timbul seharusnya ditulis menimbulkan dengan menggunakan prefiks meng- varian men- serta diikuti sufiks -kan atau konfiks men-...-kan (penghilangan konfiks men-...-kan). Menurut Depdiknas (2008:1194) menimbulkan adalah mengeluarkan ke atas; membangkitkan kembali; mengakibatkan atau mendatangkan; dan menjadikan. Dengan demikan kalimat pada data (16) dapat diperbaiki menjadi, "Jika ada kesalahan, bisa jadi menimbulkan perang besar yang risikonya bisa melenyapkan Korut.."

Data 17

Membuka pintu untuk memasuki jalan perdamaian pun tidak akan terjadi jika, sekali lagi, tidak akan saling percaya (17). (Publikasi Sabtu, 25 Februari 2017 dengan judul tajuk "Perdamaian Masih Jauh dari Suriah")

Berdasarkan data (17) di atas, penulisan percaya tidak sesuai dengan aturan atau kaidah bahasa Indonesia. Kesalahan tersebut terjadi karena penghilangan afiks (prefiks, sufiks, infiks, konfiks) khususnya penghilangan prefiks meng- (varian me-, mem- 
, men-,menge- meny-) pada kata percaya. Penulisan kata percaya seharusnya ditulis memercayai dengan menggunakan prefiks meng- varian mem- serta diikuti sufiks $-i$ atau konfiks mem-...-i (penghilangan konfiks mem...-i). Menurut Depdiknas (2008:856) memercayai adalah menganggap benar atau nyata; mengakui benar atau nyata; mengaharapkan benar atau memastikan (bahwa akan dapat memenuhi harapannya dan sebagaiinya). Dengan demikan kalimat pada data (17) dapat diperbaiki menjadi, "Membuka pintu untuk memasuki jalan perdamaian pun tidak akan terjadi jika, sekali lagi, tidak akan saling memercayai"

Data 18

Kita hanya bisa berharap Pemimpin Korut semakin dewasa, matang, dan arif bijaksana, dan kuasa dunia (termasuk AS dan China, juga PBB) tidak henti-hentinya membujuk Pyongyang untuk berdamai dengan Seoul, serta lebih fokus (18) pada pembengunan negerinya. (Publikasi Selasa, 28 Februari 2017 dengan judul tajuk "Ancaman dari Korea Utara")

Berdasarkan data (18) di atas, penulisan fokus tidak sesuai dengan aturan atau kaidah bahasa Indonesia. Kesalahan tersebut terjadi karena penghilangan afiks (prefiks, sufiks, infiks, konfiks) khususnya penghilangan prefiks meng- (varian me-, mem, men-,menge- meny-) pada kata fokus. Penulisan kata fokus seharusnya ditulis memfokuskan dengan menggunakan prefiks meng- varian mem- serta diikuti sufiks -kan atau konfiks men-...-kan (penghilangan konfiks mem-...-kan). Menurut Depdiknas (2008:319) memfokuskan adalah memusatkan (perhatian, pembicaraan, pandangan, sasaran, dan sebagainya). Dengan demikan kalimat pada data (18) dapat diperbaiki menjadi, "Kita hanya bisa berharap Pemimpin Korut semakin dewasa, matang, dan arif bijaksana, dan kuasa dunia (termasuk AS dan China, juga PBB) tidak henti-hentinya membujuk Pyongyang untuk berdamai dengan Seoul, serta lebih memfokuskan pada pembengunan negerinya."

\section{SIMPULAN}

Kesalahan berbahasa dalam tajuk rencana surat kabar Kompas terdapat kesalahan berbahasa dalam tataran morfologi khususnya penggunaan afiks yang tidak tepat di antaranya proteksionis (penggunaan sufiks -is), proteksionistis (penggunaan sufiks $-i s$ ), penghilangan afiks di antaranya jelang (penghilangan prefiks mengvarian men-), perlu (penghilangan konfiks mem...-kan), tahu (penghilangan konfiks menge-...-i), retorika (penghilangan prefiks ber-), perlu (penghilangan konfiks di-...-kan), punya (penghilangan konfiks mem-...-i), relokasi (penghilangan prefiks me-), lupa (penghilangan konfiks me-...-kan), menyebut (penghilangan sufiks -kan), kenapa (penghilangan prefiks meng- ), dilapori (penghilangan sufiks -kan), timbul (penghilangan konfiks men-...-kan), percaya (penghilangan konfiks mem-...-i), fokus (penghilangan konfiks mem-...-kan)

\section{DAFTAR PUSTAKA}

Alwi, Hasan dkk. 2003. Tata Bahasa Baku Bahasa Indonesia. Jakarta: Balai Pustaka.

Arifin. Dkk. 2009. 1001 Kesalahan Berbahasa. Jakarta: Akademika Pressindo.

Ayya, Nur. 2014. "Analisis Kesalahan Berbahasa dalam Tataran Sintaksis pada Blog Dosen FKIP UIR". Skripsi. Pekanbaru. FKIP UIR.

Badudu, J. S. 1988. Cakrawala Bahasa Indonesia. Jakarta: Gramedia.

Chaer, Abdul. 2002. Pembakuan Bahasa Indonesia. Jakarta: Rineka Cipta. 2007. Linguistik Umum. Jakarta:

Rineka Cipta. 2009. Pengantar Semantik Bahasa

Indonesia. Jakarta: Rineka Cipta.

Depdiknas. 2008. Kamus Besar Bahasa Indonesia. Jakarta: PT Gramedia Pustaka Utama.

Dilla, Cendi Fika dkk. 2013. Penggunaan Kalimat Efektif Pada "Haluan Kita" Surat Kabar Haluan Padang. Jurnal Bahasa Indonesia. Vol. 02, No. 6 http://ejurnal.bunghatta.ac.id/index.php ?journal $=$ JFKIP \& page $=$ article \&op $=$ vie w\&path\%5B\%5D=1981 \&path\%5B\%5D $=1772$ (diakses 10 Agustus 2016). 
Gunawan, Imam. 2013. Metode Penelitian Kualitatif Teori \& Praktik. Jakarta: Bumi Aksara.

Hamidy, UU dan Yusrianto. 2003. Metodologi Penelitian. Pekanbaru: Bilik Kreatif Press

Http//:www.m.kompasiana.com/pengertianmedia-massa. Diakses pada 16 Maret 2016.

Http://www.riauterkini.com/riauterkini. Diakses pada 18 Maret 2016.

Keraf, Gorys. 1987. Tata Bahasa Indonesia. Flores NTT: Nusa Indah. .1991. Tata Bahasa Indonesia. Jakarta: Nusa Indah.

Kridalaksana, Harimurti. 2008. Kamus Linguistik Edisi Keempat. Jakarta: PT Gramedia Pustaka Utama.

Krippendorff, Kalus. 1991. Analisis Isi: Pengantar Teori dan Metodologi. Jakarta: Rajawali Pers.

Lubis, Hamid Hasan. 1993. Jenggala Bahasa Indonesia. Bandung: Angkasa Bandung.

Mardalis. 2014. Metodologi Penelitian suatu Pendekatan Proposal. Jakarta: Bumi Aksara.

Nawangsasi, Endah. 2015. "Analisis Kesalahan Berbahasa Mahasiswa S1 Manajemen tahun 2011 STIE AUB Surakarta" jurnal Pro-Bank Vol 1 No 1 2015, edisi Maret (https://www.google.com/search?clien $\mathrm{t}=$ firefox-b-

$a b \& q=j u r n a l+a n a l i s i s+k e s a l a h a n+b e r b$ ahasa+dalam+bidang+morfologi\&oq= jurnal+analisis+kesalahan+berbahasa+ dalam+bidang+morfologi\&gs $1=$ psyab.3..0i30k1.43825.45902.0.48842.7.7 $.0 .0 .0 .0 .330 .1427 .0 \mathrm{j} 1 \mathrm{j} 4 \mathrm{j} 1.6 .0 \ldots . .0 \ldots 1.1$. 64.psyab..1.6.1410...0i13k1j0i13i30k1j0i13i 5i30k1.eELwzelu1QA, diunduh 14 Agustus 2017).

Pranowo. 2014. Teori Belajar Bahasa. Celeban Timur: Pustaka Pelajar.

Priyoko, Yakub. 2012. Analisis Kesalahn Berbahasa Bidang Morfologi pada Mading di Universitas Muhammadiyah Surakarta.
http://eprints.ums.ac.id/21049/15/JUR

NAL_ILMIAH.pdf

Rahman, Elmustian. 1998. Bahasa Jurnalistik. Pekanbaru: UNRI Press.

Ramlan. 2001. Ilmu Bahasa Indonesia Sintaksis. Yogyakarta: CV Karyono. 2005. Ilmu Bahasa Indonesia

Sintaksis. Yogyakarta: CV Karyono.

Sari, Amalia Ayu. 2013. Kesalahan Berbahasa dalam Tataran Frasa dalam Karangan siswa kelas VIII SMP Negeri 30 Semarang. http://lib.unnes.ac.id/18776/1/2601490 47.pdf.17 Maret 2016.

Sudaryanto. 1988. Metode Linguistik Bagian Pertama ke Arah Memahami Metode Linguistik. Gadjah Mada University Press.

Setyawati, Nanik. 2010. Analisis Kesalahan Berbahasa Indonesia. Surakarta: Yuma Pustaka.

Sugiyono. 2012. Metode Penelitian Kuantitatif Kualitatif dan $R \& D$. Bandung: Alfabeta

Sujarweni. 2014. Metodologi Penelitian. Yogyakarta: Pustaka Baru Press.

Tarigan, Henry Guntur. 2009. Prinsip-prinsip Dasar Sintaksis. Bandung: Angkasa. - 2011. Pengajaran Pemerolehan Bahasa. Bandung: Angkasa.

Tarigan, Henry Guntur dan Djago Tarigan. 2011. Pengajaran Analisis Kesalahan Berbahasa. Bandung: Angkasa.

Verhaar, dkk. 2010. Asas-asas Linguistik Umum. Yogyakarta: Gadjah Mada University Press.

Widi, Restu Kartiko. 2010. Asas Metodologi Penelitian. Yogyakarta: Graha Ilmu. 